\title{
Household-microenterprise - the missing link in gendered value chain analysis: lessons from an analysis of dairy chains in Nicaragua
}

\author{
SELMIRA FLORES and JOHAN BASTIAENSEN
}

In Nicaragua, gender analysis in value chains is usually restricted to a study of men and women as producers or workers within the chain itself. This overlooks many relevant dimensions of gender struggles. We therefore propose a gender analysis in value chains that pays attention to the interrelation of the value chain with intra-household dynamics in microenterprises and the broader community. We apply our approach to two dairy chains, not to compare which is better for women producers but to show the gender complexity in both that needs to be considered in value chain analyses. Based on case studies, we identify gender differentiation overlapping with conflictual-cooperative relations between men and women within the sphere of economic and family relations in the two dairy chains.

Keywords: gendered value chain analysis, household-farm, household-microenterprises, dairy chains, Nicaragua

THIS ARTICLE PRESENTS AND ILLUSTRATES an integrated framework for Gender Analysis in Value Chains (GinVC) in Nicaragua. Currently, most known studies (Flores and Lindo, 2006; Lyon et al., 2010; Sender et al., 2014) analyse differences between women and men within value chains in terms of employment, wages, working conditions, and workload, particularly focusing on locations where women have a strong visible presence (Tallontire et al., 2005). That approach focuses on female producers gaining internal economic power (Coles and Mitchell, 2011), i.e. becoming more involved in chain management (KIT et al., 2012). It leads GinVC research to centre on incorporating women and upgrading their position in the technical-productive processes and associated economic relationships (Gereffi and Korzeniewicz, 1994; Kaplinsky and Morris, 2001; Mayoux and Mackie, 2007). While this analysis is useful, it tends to ignore the actors' background as gendered beings in broader social relationships. We therefore try to overcome the limitations of this approach by incorporating an analysis of gender dynamics in household-microenterprises and the broader community. These dynamics relate to what Bourdieu (1998) called 'doxa': principles and norms that people embrace as the natural order and no longer recognize as contingent human creation, even though they constitute the subject of continuous

Selmira Flores, PhD (sflores@nitlapan.org.ni) is Research Director at Nitlapan, Universidad Centroamericana, Nicaragua; Johan Bastiaensen is Professor at the Institute of Development Policy and Management, University of Antwerp, Belgium.

(C) Practical Action Publishing, 2017, www.practicalactionpublishing.org http://dx.doi.org/10.3362/1755-1986.16-00028, ISSN: 1755-1978 (print) 1755-1986 (online) 
contestation, struggle, and thus change. Our approach to GinVC aims to reveal these hidden struggles over the gendered doxa in households and the community. Such analysis not only digs deeper than the more visible dimensions of gender constraints (lack of access to formal property or credit and mobility restrictions). It also avoids treating women as a homogeneous group characterized solely by their place and functions within the VC, but rather by a combination of identity markers beyond gender itself, such as age, marital status, and membership in social organizations (Crenshaw, 1991; Mc Call, 2005; Davids and van Driel, 2007).

We illustrate our approach with two case studies of dairy chains in Matiguás, Nicaragua (Flores, 2015). The case studies draw extensively on the first author's experience - since 2005 - as a consultant-researcher-trainer in gender projects and value chain studies, including the elaboration of specific methodological material to incorporate gender into value chain analyses in Nicaragua (Flores and Lindo, 2006). The specific information for the analysis of the case studies in Matiguás comes from extensive semi-structured interviews with 12 local managers of milk collection centres (two of them women) complemented with data about milk production obtained from milk collection centres in 2010. In addition, we organized three focus groups on evolving gender relations in the fresh milk chain (two with women - 23 in total - and one with 10 men, all cooperative members). We further carried out 10 case studies of local dairy processors producing cuajada (a soft compacted white curd cheese) and an additional 10 interviews with local and national stakeholders in government and non-governmental organizations.

\section{Types of dairy value chains in Matiguás, Nicaragua}

In Nicaragua, one can identify six complementary types of dairy chains connecting milk-producing farmers with different market segments (Artola and Parrilli, 2003; Flores and Artola, 2004; Flores, 2015). In urban areas, we first can find short and small informal chains for fresh milk directly connecting peri-urban farmers with consumers. Then, there are two much more extended cottage dairy chains: the mantero and the cuajada chain, which respectively produce hard, dry white cheese in large 20 to $50 \mathrm{lbs}(9-23 \mathrm{~kg}$ ) blocks and soft fresh cheese, processed into small, hand-formed balls (cuajada) as well as sour cream. Both chains supply the popular demand for traditional dairy sold in the markets - the Ivan Montenegro Market in the capital Managua in particular. Both continue to process a substantial amount of milk from the remote interior areas of Nicaragua in low-technology, often home-based artisanal plants. Next is the chain of semi-industrial cheese factories, also located near the producing areas in the interior of the country, which are largely controlled by Salvadoran exporters. They originally processed milk into cheese for export to the Salvadoran market in slightly upgraded plants, but today operate differentiated cheese plants, also partially for export to the US. A fifth chain is formed by upgraded producer cooperatives who collect their own milk to produce the 'morolique cheese' for export to El Salvador and Honduras. Finally, there is the fresh milk chain which links producer cooperatives with the large industrial dairy processing companies. In these chains, which process around 30 per cent of the total 
supply, milk is collected and cooled in (often cooperative) milk collection centres and transferred to industrial plants near the capital. The chains produce a variety of processed dairy products catering to supermarkets and neighbourhood shops while some export to Central America and Venezuela.

In order to apply our approach to GinVC, our analysis in Matiguás focuses on two local versions of industrial fresh milk and cuajada chains, which are largely segmented with few interactions and virtually no actors involved in both chains. Each has different requirements of volume, quality, and timing of milk delivery as well as institutional conditions (like cooperative membership). Because the cuajada business is historically female-dominated while milk production and cooperative membership are considered male-dominated, it is often presumed that the former would hold more opportunities for female participation and gender justice. Our GinVC analysis of both chains, however, indicates that the dynamics of gender relations and struggles are less simple and straightforward than often assumed, such that progress and regress in gender equality and female entrepreneurship can take place in both chains.

Figure 1 presents the different actors and their roles within these dairy chains, from input suppliers, milk production, and milk processing to marketing. We reiterate that our aim is not to compare them or evaluate which one offers better perspectives for gender justice; it is rather to present the diversity and complexity of the gendered socioeconomic context in which both chains are embedded, and the need to incorporate this in the GinVC analysis. As we will illustrate below, taking due account of this contextualized embeddedness is critical in order to analyse and deconstruct gender relations such as to inform adequate value chain interventions.

The fresh milk industrial chain is the most dynamic segment of dairy chains in the country and its network of collection centres with tanks for cooling milk in central rural sites like Matiguás has good access to paved roads, water, and electricity. From a VC perspective, it is often held to represent the most advanced form of dairy production, based on industrial processing and branding as well as the observance of the highest hygienic standards. In Matiguás, 15 collection centres have been established with public support, and an annual average value added per litre of milk in 2011 was estimated to be some C\$9.32 (US\$0.43) in total, with a value of C\$3.08 (US\$0.14) per litre of milk remaining in Matiguás, as illustrated at the bottom of the last column in Table 1.

At first sight, this industrial-cooperative chain appears to be an exclusively male domain. However, many women participate as largely invisible family memberworkers in the farm-households and even as a significant minority of female owner-producers in the cooperatives or as individual suppliers. According to 2011 data, women producers in cooperatives accounted for 13 per cent of membership (out of 740 cooperative members) and contributed 14 per cent of the milk collected. Two women, out of total of 15 managers, manage two milk collection centres, one in a cooperative and another in a private collection centre.

The cuajada chain is a more local, shorter chain, in which female-owned home-based microenterprises predominate. The chain structure is presented in Figure 2. 


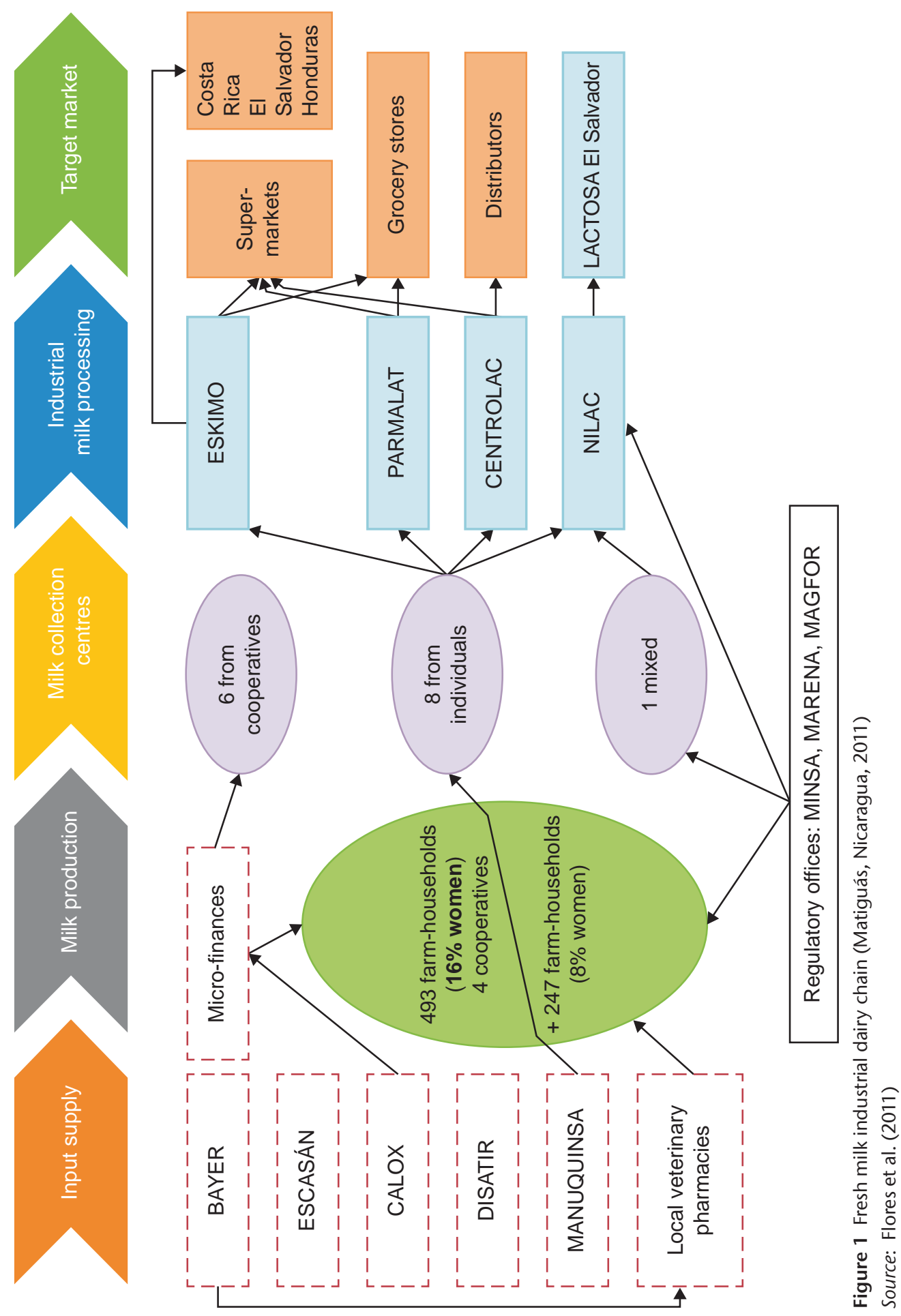




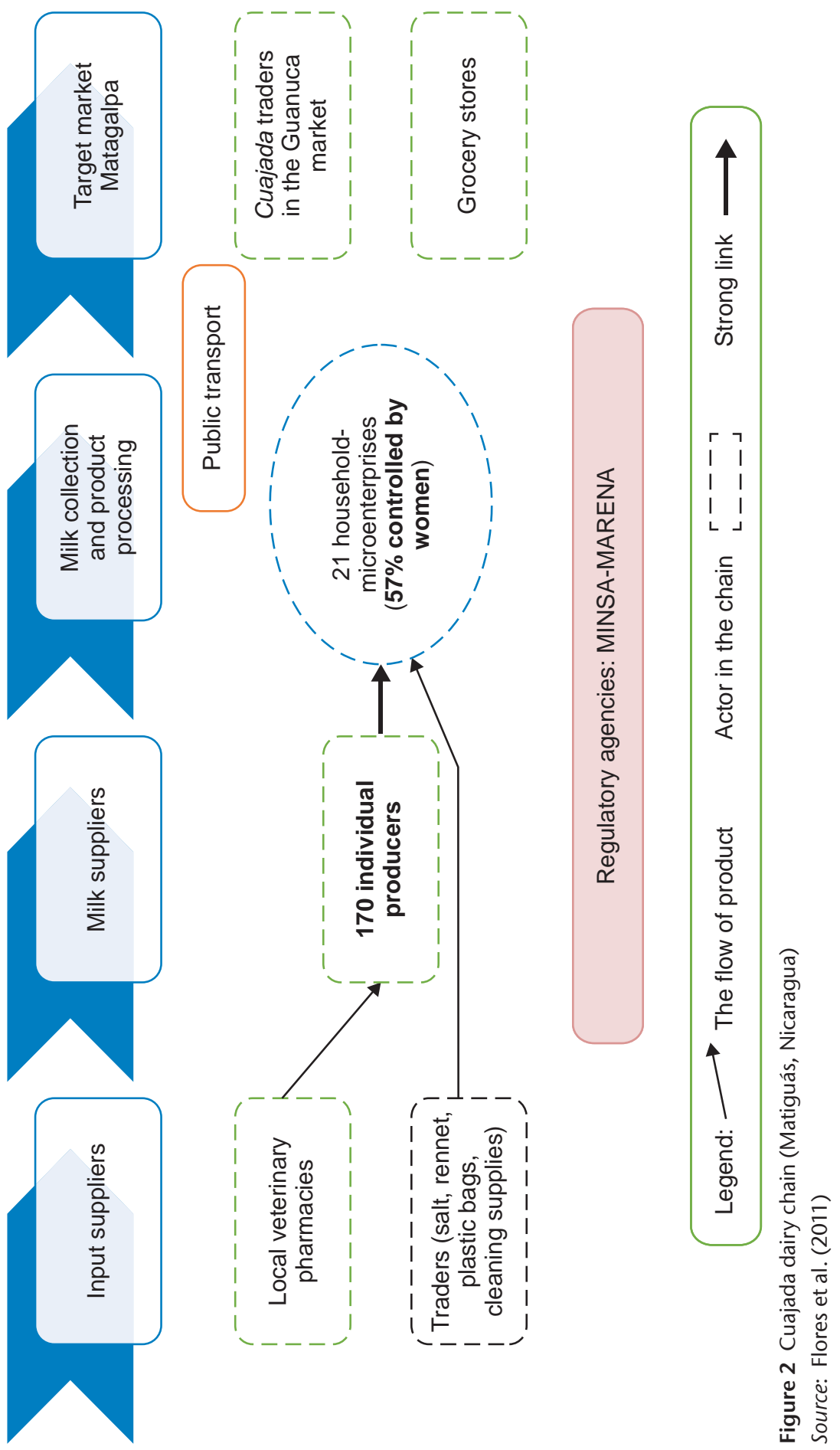


Table 1 Value added per litre of milk in the fresh milk industrial chain (Córdobas/litre)

\begin{tabular}{|c|c|c|c|c|c|c|}
\hline \multirow[t]{2}{*}{ Actors (fresh milk chain) } & \multicolumn{2}{|c|}{ Dry season } & \multicolumn{2}{|c|}{ Rainy season } & \multicolumn{2}{|c|}{ Annual average } \\
\hline & VA $(C \$ /$ litre $)$ & $\%$ & VA $(C \$ /$ litre $)$ & $\%$ & VA (C\$/litre) & $\%$ \\
\hline Producers & 3.37 & 33 & 2.37 & 28 & 2.87 & 31 \\
\hline Collection centres & 0.19 & 2 & 0.24 & 3 & 0.21 & 2 \\
\hline Processing industry & 4.61 & 45 & 3.61 & 43 & 4.11 & 44 \\
\hline Retailers & 2.00 & 20 & 2.25 & 27 & 2.12 & 23 \\
\hline Total value added & 10.17 & 100 & 8.47 & 100 & 9.32 & 100 \\
\hline Value added in & $C \$ 3.56$ & & $C \$ 2.61$ & & $C \$ 3.08$ & \\
\hline Matiguás & US\$0.16 & & US\$0.12 & & US\$0.14 & \\
\hline
\end{tabular}

Note: US $\$ 1=\mathrm{C} \$ 21.47$

Source: Flores et al. (2011)

In Matiguás, the household-based cuajada processing microenterprises are related to a total of 170 milk producers and about 25 female dairy traders in the Guanuca market of the departmental capital, Matagalpa City. These milk suppliers do not take part in milk cooperatives because of their location, smaller production volumes, and/or preference to recover the whey to use it for home-based pig production. Most of them are, however, located close to processing microenterprises. This chain generates less value added $(\mathrm{C} \$ 6.67=\mathrm{US} \$ 0.31)$ for each litre of milk (see Table 2$)$ than the fresh milk chain (C\$ 9.32=U U0.43; see Table 1). However, as all milk leaves the production area locally processed, this chain leaves higher value added in Matiguás (US\$0.20 vs. US\$0.14).

We identified two distinctive types of cuajada microenterprises. One consists of more consolidated and diversified household-microenterprises that process a variety of dairy products and perform various other income-generating activities such as petty sales (house-front shops), sale of food, and the purchase and sale of pigs. Some also have their own cattle farms to supply them with their own milk. The other is

Table 2 Value added in dry and rainy season in the cuajada chain in Matiguás ( $C \$ /$ litre)

\begin{tabular}{|c|c|c|c|c|c|c|}
\hline \multirow[t]{2}{*}{ Actors (cuajada chain) } & \multicolumn{2}{|c|}{ Dry season } & \multicolumn{2}{|c|}{ Rainy season } & \multicolumn{2}{|c|}{ Annual average } \\
\hline & VA (C\$/litre) & $\%$ & VA (C\$/litre) & $\%$ & VA (C\$/litre) & $\%$ \\
\hline Producers & 2.66 & 33 & 1.36 & 26 & 2.01 & 29 \\
\hline Cuajaderas & 3.5 & 43 & 1.99 & 38 & 2.74 & 41 \\
\hline Wholesalers & 1.2 & 15 & 1.2 & 23 & 1.2 & 19 \\
\hline Retailers & 0.71 & 9 & 0.71 & 13 & 0.71 & 11 \\
\hline \multirow[t]{2}{*}{ Total VA } & 8.08 & 100 & 5.27 & 100 & 6.67 & 100 \\
\hline & $C \$ 6.16$ & & $C \$ 3.35$ & & $C \$ 4.75$ & \\
\hline VA in Matiguás & US\$0.28 & & US\$0.15 & & US\$0.22 & \\
\hline
\end{tabular}

Note: US $\$ 1=C \$ 21.47$

Source: Flores et al. (2011) 
Table 3 Estimated monthly costs and income: selected cuajada household-microenterprises in Matiguás

\begin{tabular}{lccccc}
\hline Cases & Cost $(C \$)$ & Gross income $(C \$)$ & Total income (C\$) & Total income (US\$) & Type \\
\hline Case 1 & 141,155 & 154,440 & 13,285 & 559 & Diversified \\
Case 2 & 25,720 & 42,110 & 16,390 & 689 & \\
Case 3 & 77,520 & 97,230 & 19,710 & 828 & \\
Case 4* & 274,235 & 289,480 & 15,245 & 640 & \\
Case 5 & 186,100 & 198,000 & 11,900 & 500 & \\
Case 6 & 245,676 & 260,520 & 14,844 & 624 & \\
Case 7 & 19,025 & 24,930 & 5,905 & 248 & Non- \\
Case 8* & 90,465 & 93,500 & 3,035 & 128 & Diversified \\
Case 9 & 39,520 & 43,970 & 4,450 & 187 & \\
Case 10 & 14,820 & 16,000 & 1,180 & 50 & \\
\hline
\end{tabular}

* Owner of the cuajada business is a man

Exchange rate: US $\$ 1=C \$ 23.80$

Source: Diagnostic report on female micro-entrepreneurs (SDE-Nitlapan, 2012)

much less diversified, processing only one or two products, and also having fewer alternative income-generating activities. Diversified cuajada microenterprises obtain substantial net monthly income from this activity (Table 3).

Among the challenges of this chain is the need to consolidate its access to local milk supply in the face of competition from the industrial and semi-industrial chains, which requires some technological upgrading and a product differentiation and 'branding' strategy by catering to existing or new complementary niche markets (Turner, 2006).

\section{Interpreting gender relations in dairy chains in Matiguás}

Following our integrated framework, we now describe ambiguities and contradictions of the complex, often hidden gender relations at play within both dairy chains. Co-dependent upon age, marital status, and cooperative membership, different and evolving female roles recreate gender relations in a process that moves between continuity and change. Each specific feature of these relations involves struggle and negotiation, conflict and cooperation at the same time. To understand this, we need to avoid homogenizing women and men as well as farms, households, and microenterprises in our VC analysis. Instead, it is necessary to focus on their particularities in time and space so as to deal with different constraints or opportunities arising from specific gender dynamics.

\section{Presence-absence of rural women within the farm-household}

The typical image in dairy VC analysis, identifying milk producers as predominantly men who are in charge of their cattle farms (Ammour, 2009; Eskola, 2003), hides a reality of farm-households with intensive female participation. Many women and 
other family members participate intensively in cattle care, milking, milk delivery, and milk processing. This omnipresent reality of family work is seldom recognized publicly. Even when as many as 3 out of 10 milk suppliers in the country are farms controlled by women (Flores and Artola, 2004), this huge female presence is considered the exception that confirms the rule. This persistent lack of recognition and the misrepresentation expresses the still dominant cattle doxa of patriarchal control and domination. Nonetheless, hidden behind this bleak reality of persisting female 'invisibility' is an intense ongoing struggle and negotiation about margins of decision-making power and recognition within the household-farms.

\section{Gender, age, and marital status within the first link of the dairy chains (farm-household)}

Our analysis has identified at least four different realities of women in farmhouseholds. A first is that of older widows in charge of a farm-household inherited from their husbands. Widowhood provides a status that allows male producers to recognize women's roles as cattle producers, particularly if she remains unmarried and is supported by her sons. In this circumstance a woman can achieve legitimate status as a cattle producer and even gain the right to join a cooperative, although her age and marital condition (widowhood) would make it difficult to aspire to become part of the directive board. However, if the widow is a young adult as in Alma's case (33 years old, owner of 12 cows and managing to produce $40-45$ litres of milk daily - above the minimum volume required - and working on a plot of land that still belongs to her father-in-law), she has to deal with a lot of uncertainty about the property and livestock because, as she commented, 'rumour has it that my fatherand brothers-in-law want to take the land and part of the livestock'. As she is a young widow, it is popularly assumed that almost certainly a man will appear to 'conquer' her and offer her his home, while appropriating the family land and livestock. Since her cows and paddocks are distant from the house, she also faces time constraints to combine household chores with farm management, since she needs to take care of her young children, particularly in the morning when she should be overseeing the milking by her male workers. On top of that, the doxa of the male cattle domain also generates active resistance among her workers to having to respond to a woman owner, inviting them to engage in shirking and even sabotage. Ultimately, these constraints entail the risk of being excluded from the cooperative (and thus from access to the fresh milk chain) for being unable to guarantee the necessary quality and volumes of milk at the required time. Even when we found Alma struggling to survive as an independent widow-dairy producer, her prospects for success were not very positive in the face of the superimposed constraints.

In a second reality, contrary to the widespread male-dominated farm-household, we also found a minority of households in which women work alongside their husbands, co-manage the farm, and enjoy relative autonomy, for instance signing up as a milk supplier in the collection centre. One husband stressed that 'In our case, both she and I make decisions; we have also incorporated our children as members of the cooperative, each with their own cows and their own milk, while all our cows graze together. If I realize that a barbed wire fence needs to be fixed, 
we divide the cost'. This kind of farm-household develops an atypical trajectory of cooperation and negotiation among all family members. In many other farmhouseholds, women assist their husbands but their voices are not considered. As one woman commented:

If I see a sick animal, I tell [my husband] what to do, but he never believes me ... If the animal doesn't get better, he'll look for a technician ... If I tell him what to do, he tends to ignore it, but if someone else comes and tells him the same, then he believes it. The problem is that men think women don't know anything and can't learn (Group discussion with female members in the Nicacentro cooperative).

Our analysis of the divergence between the two types of gender relations within farm-households, male attitudes in particular, points to differences in family history as an explanation. Men with more egalitarian attitudes towards their spouses and children often grew up in single-mother families, while men with more traditional authoritarian attitudes had lived in families with strong fathers. Such differences in social background and their influence on intra-household relationships in the farm production units indicate a need to think about differentiated strategies to support women and to approach men either by supporting them in their atypical democratic attitudes or trying to convince them to change their views from rigid authoritarian positions.

\section{Gender, farm-leadership, and cooperative membership}

A third reality of women in dairy cattle is that of women farm-managers with cooperative membership, who are engaged in a series of interconnected struggles to defend their agency (Gardiner, 1995) in the face of multiple adversities. In particular, they cannot count on the support of their respective cooperative, which fails to recognize and address their specific needs as female members. Zoyla and Martha, two farm managers, illustrate their multiple struggles in gender continuity and change. Zoyla manages and represents the farm in place of her absent husband, while Martha operates for her father. Both struggle to govern their male workforce since 'men are reluctant to take orders from women' (focus group with Nicacentro cooperative members). In the collective self-image of the cattle doxa, taking orders means being in a subordinate position and subordination equals femininity. As Zoyla testified:

I would hand the foreman the necessary number of fence staples, then he'd come back asking for more, telling me he'd used them up. That struck me as odd and I wondered if I was figuring it right. ... I later found out he was wasting the staples or throwing them away. He did the same with the livestock medicine just to make me spend more money. ... My initial reaction was to get upset.

Female producers thus incur economic losses, which then cast subtle doubts on their ability to manage a cattle farm on an equal footing with men.

In Martha's case, being the oldest daughter, single, and a professional working in the city, she replaced her sick father in the farm management. Although she grew 
up on the farm and the foreman knows her, he reacted poorly when she assumed the farm leadership based on the idea that she was unprepared to deal with cattle and related activities. She quickly noted milk reduction, which was impacting the income. In her words:

When I realized what was happening, I instructed the foreman not to milk any cows and I myself measured the milk of each and every cow. What was he doing? He and another worker were first milking the cows in the paddock. They tried to trick me, so I fired him [the foreman].

According to her, the foreman's behaviour would never have occurred when her father was running the farm, also because he used to spend more time there, while she is forced to divide her time between farm administration and taking the milk to the collection centre in the morning, supporting her mother in caring for her father, and meetings with the cooperative board. These partially hidden gender conflicts clearly affect women's performance within the value chain (lower productivity and profit). Nevertheless, these women persist in their efforts to run their family's farm, and thus gradually move some borders of the prevailing gender norms.

\section{The re-creation of gender relations in household-microenterprises}

In the cuajada chain, the fourth reality, we found similar re-creations of gender conflicts and cooperation in the household-microenterprise, influencing both women's initial entrepreneurial initiative and the prevalence of surprising levels of male involvement in this historically 'female' subsector. We also observed that women and men can and do often act in ways that are different from what the dominant gender-defined codes and rules prescribe (Messer, 1995). The group of female cuajada entrepreneurs we interviewed had all married under the age of 20, following the rural gender norm to become housewives and mothers after leaving home (at around 15 years old). None of them inherited any productive assets even though four were from families that owned land and livestock. In their accounts, their husbands' insufficient income (they worked as livestock farm foremen or agricultural day labourers) initially encouraged the women to perform some activities to earn additional income and pay for their household's basic necessities. Over the years, they added greater value to the output produced within the household. In 4 of the 10 cases, the women's economic activity went against their husband's wishes, but their success and persistence in generating additional income has clearly helped change perceptions about women's traditional economic dependence on their husbands. This persistence is directly connected to the struggle to survive in poverty conditions, dealing not just with income scarcity but also with traditional gender roles in rural communities and the impossibility of continuing them in a poverty context. The possibility of modifying such roles is facilitated when the lack of resources affects both men and women. These entrepreneurial rural women defended their position, carving out some room for manoeuvre, as Villarreal (1992) mentions, between what they were not supposed to do (defy their husband) and what they actually did (reassert their identity as micro-entrepreneurs). Thus, influenced by the interaction 
of poverty and gender norms, some couples experienced a push-pull game (Agarwal, 1997) in which they changed their gender relations because the woman's position as income generator challenged the breadwinner function normally reserved for men. Eventually, the husbands also benefited from the women's entrepreneurial success since they could make money faster than the mem.

In the other six cases, the husbands' attitude towards women participating in income generation was positive from the start. Again, we observed that these men had single mothers and had learned to help them out even with household chores. For us, it seems that these men's positive attitude was influenced by the fact that they witnessed how their mothers had to struggle and showed they were capable of more than women are given credit for. Beyond being driven by lack of money, however, these rural women's option to try commercial activities and leave their houses to sell what they produced also reveals, as Macleod (1993) pointed out, that women struggle and contest. All of them agreed that they played a different role from that of their mother in the household, in particular having to be supported by their husband, sometimes giving up their property (land and livestock) for their husband to work, and complying with what he said even when they did not agree (as mentioned in interviews with cuajada entrepreneurs).

The gender relations are re-configured in an interactive game within the household where women's micro-level practices are evidence of their agency with ramifications for the wider structuring of the family economy (Carswell and De Neve, 2012). The cuajadera cases allow us to see how they re-created gender relations in a process in which both women and men struggle and collaborate.

\section{Leading women and more equal participation in the family business}

Even though cuajada production has historically been women's activity, men's involvement as owners of this kind of business or helping their mother or wife in it also introduces a significant change. The business is no longer women's exclusive domain even though women continue being the main performers of this activity. In Matiguás, we found cuajada microenterprises where men make the most important decisions. However, only 2 of the 10 microenterprises are run by both husband and wife, and in those cases the man is the main decision-maker. In the other eight, even though their husband or sons contribute to the decision-making, the women lead and make the business as well as budget decisions.

Our research indicates that men tend to get involved in cuajada production influenced by constraints some face in getting access to their historical male jobs (usually farming). These restrictions prompt men to get directly involved in the space normally reserved for women within the household. The reality of Matiguás reveals several relatively successful home-based milk processing microenterprises; many of them run by women in rural communities. These businesses represent a realm of positive gender change for women, for instance more revenue and clear contribution to the family income, a higher degree of participation in decision-making and more autonomy and mobility. It has been a process in which the male partners changed part of their male gender norms. The home-based cuajada-processing enterprises enable family members to build more equal relations. Women are respected, helped, 
and supported by their husbands and sons as they become the main family income generators. This does not imply an absence of conflicts, but the cases illustrate that women provide their families with money on a weekly basis, whereas their husbands have to wait for the completion of the harvest cycle or sale of livestock, which takes place only two or three times a year. Even under precarious situations and with limited resources, women have taken further complementary initiatives for their family income generation either by themselves or together with their husbands or sons.

\section{Conclusion}

Gender in value chain analysis requires examining the distinctive ways in which women and men interact in different spaces within the farm-household and community, and how these interact with their operations in the value chain. In the context of dairy production, this particularly requires surmounting the false perspective of milk production controlled individualistically by the male family-head and farm ownermanager, making way for a more realistic view of the collective action that de facto exists in farm families. Instead of looking for structural similarities among 'women' or 'men' in the value chain, farm-households, or household-microenterprises, gender analysis in value chains should pay attention to outliers or in other cases, emerging differences, within the complex processes of continuity and change in gendered social realities. Identifying differences would allow patterns to be identified that could be enhanced (i.e. where men recognize and defend women's right to manage their own properties or be farm administrators) or should be fought (i.e. where women cannot make decisions or those oriented to sabotage women's agency). Therefore, gender analysis should emphasize variegated actions according to relevant differences that might become opportunities to foster gender equality.

\section{References}

Agarwal, B. (1997) 'Bargaining and gender relations within and beyond the household', Feminist Economics 3(1): 1-51.

Ammour, T. (2009) Acceso a mercados de pequeños productores en América Latina. Estudio de caso de la leche en la Cooperativa San José (CASANJO) Matagalpa, Nicaragua [online] <http://nuevo. rimisp.org/FCKeditor/UserFiles/File/documentos/docs/> [webpage no longer available].

Artola, N. and Parrilli, M. (2003) El despegue del sector lácteo in Boaco y Chontales en Nicaragua, Managua: Agorà, 2000 mimeo for IDB.

Benería, L. (2008) 'De la armonía a los conflictos cooperativos. La contribución de Amartya Sen a la teoría de la unidad doméstica', Araucaria, Revista Iberoamericana de Filosofía, Política y Humanidades 20: 15-34.

Bourdieu, P. (1998) Practical Reason, on the theory of action, Stanford, CA: Stanford University Press.

Carswell, G. and De Neve, G. (2012) 'Labouring for global markets: conceptualising labour agency in global production networks', Geoforum 44: 62-70 <http://dx.doi.org/10.1016/j. geoforum.2012.06.008>. 
Coles, C. and Mitchell, J. (2011) Gender and Agricultural Value Chains: A Review of Current Knowledge and Practices and their Political Implications [online], ESA Working paper No.11-05, FAO <http://www.fao.org/docrep/013/am310e/am310e00.pdf > [accessed 1 March 2017].

Crenshaw, K. (1991) 'Mapping the margins, intersectionality, identity politics and violence against women of color', Stanford Law Review 43(6): 1241-99.

Davids, T. and van Driel, F. (2007) The Gender Question in Globalization: Changes, Perspectives and Practices, Aldershot, UK: Ashgate.

Eskola, E. (2003) Rural Development Cooperation: Learning from Finland's International Projects and Programs, Helsinki: Ministry for Foreign Affairs of Finland.

Flores, S. (2015) Gender Dynamics in Dairy Value Chains in Nicaragua: Current Practices, Changes and Challenges, doctoral dissertation, Antwerp: IOB-Universiteit Antwerpen.

Flores, S. and Artola, N. (2004) 'La cadena de lácteos en Nicaragua, estudio de caso', in F.J. Smith (ed.), Las cadenas de valor en Nicaragua: quequisque, forestal, lácteos, tres estudios de casos, Managua: UNIFEM-PNUD.

Flores, S. and Lindo, P. (2006) Pautas conceptuales y metodológicas para el análisis de género en cadenas de valor, Managua: UNIFEM.

Flores, S. et al. (2011) La Cadena de los lácteos y su interacción con la dinámica de género en Matiguas, Managua: Cuaderno de Investigación No. 39 Nitlapan-UCA.

Gardiner, K.J. (1995) Provoking Agents, Gender and Agency in Theory and Practice, Urbana and Chicago: University of Illinois Press.

Gereffi, G. and Korzeniewicz, M. (1994) Commodity Chains and Global Capitalism, Westport, CT: Praeger.

Kaplinsky, R. and Morris, M. (2001) A Handbook for Value Chain Research [online], IDRC <www. ids.ac.uk/ids/global/pdfs/VchNov01.pdf> [accessed 11 November 2016].

KIT, AgriProFocus and ILRR (2012) Challenging Chains to Change: Gender Equity in Agricultural Value Chain Development, Amsterdam: KIT Publishers, Royal Tropical Institute.

Lyon, S., Aranda, J. and Mutersbaugh, T. (2010) 'Gender equity in fair trade - organic coffee producer organizations: case from Mesoamerica', Geoforum 41(1): 93-103 <http://dx.doi. org/10.1016/j.geoforum.2009.04.006>.

McCall, L. (2005) 'The complexity of intersectionality', Journal of Women in Culture and Society 30(3): 1771-800.

Macleod, A. (1993) Accommodating Protest: Working Women, the New Veiling, and Change in Cairo, New York: Columbia University Press.

Mayoux, L. and Mackie, G. (2007) Making the Strongest Links, a Practical Guide to Mainstreaming Gender Analysis in Value Chain Development, Addis Ababa: International Labor Office (ILO).

Messer, E. (1995) 'Acting otherwise', in K.J. Gardiner (ed.), Provoking Agents, Gender and Agency in Theory and Practice, pp. 23-51, Urbana and Chicago: University of Illinois Press.

Pietrobelli, C. and Rabellotti, R. (2004) Upgrading in Clusters and Value Chains in Latin America: The Role of Policies, Washington, DC: Inter-American Development Bank.

Sender, A., Lentink, A., Vanderschaeghe, M. and Terrillon, J. (2014) Gender in Value Chains, Practical Toolkit to Integrate a Gender Perspective in Agricultural Value Chain Development [online], Agri-Profocus <http://agriprofocus.com/upload/ToolkitENGender_in_Value_Chains Jan2014compressed14152032301426607515.pdf> [accessed 15 November 2016]. 
Tallontire, A., Dolan, C., Smith, S. and Barrientos, S. (2005) 'Reaching marginalised? Gender value chains and ethical trade in African horticulture', Development in Practice 15(3-4): 559-71 $<$ http://dx.doi.org/10.1080/09614520500075771>.

Turner, L. (2006) 'Finding a niche within a niche: discover an even more distinct market and then capitalize on it', Black Enterprise 36(7): 93.

Villarreal, M. (1992) 'The poverty of practice: power, gender and intervention from an actororiented perspective', in N. Long and A. Long (eds), Battlefields of Knowledge: The Interlocking of Theory and Practice in Social Research and Development, pp. 247-67, London: Routledge. 